\title{
Suplementação infrequente e fontes proteicas para recria de bovinos em pastejo no período seco: parâmetros nutricionais ${ }^{1}$
}

\author{
Nelcino Francisco de Paula ${ }^{2}$, Joanis Tilemahos Zervoudakis ${ }^{2}$, Luciano da Silva Cabral ${ }^{2}$, \\ Daniel Marino Guedes de Carvalho ${ }^{2}$, Mário Fonseca Paulino ${ }^{3}$, Luciana Keiko Hatamoto- \\ Zervoudakis $^{2}$, André Alves de Oliveira ${ }^{2}$, Jefferson Fabiano Werner Koscheck ${ }^{2}$
}

\footnotetext{
1 Pesquisa parcialmente financiada pelo CNPq e pela FAPEMAT.

2 Programa de Pós-Graduação em Ciência Animal, Universidade Federal de Mato Grosso (UFMT).

${ }^{3}$ Departamento de Zootecnia - UFV-MG.
}

RESUMO - Objetivou-se com este estudo avaliar os efeitos de fontes proteicas e da frequência de fornecimento de suplemento sobre o consumo e a digestibilidade dos nutrientes, as concentrações de nitrogênio amoniacal $\left(\mathrm{N}-\mathrm{NH}_{3}\right)$, o pH ruminal e o nitrogênio ureico no soro de bovinos recriados em pastagem de Brachiaria brizantha cv. Marandu no período seco. Foram utilizados cinco novilhos mestiços Nelore $\times$ Angus fistulados no rúmen, castrados, com peso médio inicial de $295 \mathrm{~kg}$ em um delineamento quadrado latino $5 \times 5$. Avaliaram-se dois suplementos isoproteicos, um com farelo de soja (FS) e outro com farelo de algodão de alta energia, fornecidos em duas frequências: diariamente (7 vezes por semana) e 3 vezes por semana (segundas, quartas e sextas-feiras); e mistura mineral (MM). A suplementação aumentou o consumo de PB, extrato etéreo (EE) e carboidratos não-fibrosos (CNF), em $\mathrm{kg}$ /dia. O suplemento com farelo de algodão o consumo de extrato etéreo. Houve efeito positivo da suplementação 3 vezes por semana sobre os consumos de matéria seca total, de forragem, de matéria orgânica de forragem, carboidratos totais (CT) e FDN. A suplementação reduziu a digestibilidade da FDN e aumentou a de PB. O suplemento com farelo de algodão reduziu a digestibilidade de FDN e carboidratos totais A suplementação 3 vezes por semana não afetou a digestibilidade dos nutrientes nem o pH ruminal. O consumo de suplemento aumenta as concentrações de $\mathrm{N}-\mathrm{NH}_{3}$, principalmente se realizado 3 vezes por semana. As concentrações de nitrogênio ureico no soro de bovinos em pastejo aumentam com o consumo de suplementos.

Palavras-chave: frequência de suplementação, pastagem, rúmen, suplementos

\section{Infrequent supplementation and protein sources for growing steers grazing in the dry season: nutritional parameters}

\footnotetext{
ABSTRACT - The objective of this study was to evaluate the effects of protein sources and frequency of supplement offer on the intake and nutrient digestibility, on the concentrations of ammonia nitrogen $\left(\mathrm{N}_{-} \mathrm{NH}_{3}\right)$, on rumen $\mathrm{pH}$ and on serum urea nitrogen concentrations in steers grazing pasture of Brachiaria brizantha cv. Marandu during the dry season. Five crossbred Zebu $\times$ Angus steers with initial live weight of $295 \mathrm{~kg}$, castrated and fitted with rumen canullae were used in a $5 \times 5$ Latin square design. It was evaluated two isoprotein supplements, one with soybean meal (SM) and the other with high energy cottonseed meal, offered at two frequencies: every day (7 times a week), or 3 times a week (on Mondays, Wednesdays and Fridays); and a mineral mixture (MM). The supplementation increased the intake of CP, of ether extract (EE) and non-fibrous carbohydrates (NFC) in kg/day. The supplement with cottonseed meal increased the intake of ether extract. There was a positive effect of the three times a week supplementation on the intakes of total dry matter, of forage, of organic matter of forage, total carbohydrates (TC) and NDF. The supplementation reduced the digestibility of the NDF and increased the digestibility of the CP. The supplement with cottonseed meal reduced digestibility of NDF and total carbohydrates. Three times a week supplementation did not affect digestibility of the nutrients neither the rumen $\mathrm{pH}$ Supplement intake increases concentrations of $\mathrm{N}-\mathrm{NH}_{3}$, especially if it is carried out 3 times a week. Concentrations of urea nitrogen in the serum of growing steers increase.
}

Key Words: frequency supplementation, pasture, rumen, supplement

Recebido em 7/7/2008 e aprovado em 6/5/2010.

Correspondências devem ser enviadas para: joanis@ufmt.br 


\section{Introdução}

A utilização de suplementos para bovinos de corte em pastejo tem sido uma das principais estratégias para intensificar os sistemas de produção, tornando-se fundamental para a competitividade e sustentabilidade do setor pecuário (Valadares Filho et al., 2006).

Nesse enfoque, uma prática que vem sendo abordada nos sistemas de produção de carne bovina é a redução na frequência do fornecimento do suplemento a animais mantidos em pastagens. Busca-se com a implementação dessa prática maior racionalização da mão-de-obra na distribuição do suplemento e redução dos custos sem afetar o desempenho dos animais (Berchielli et al., 2006).

De acordo com Köster et al. (1996), a otimização da utilização de forragens de baixa qualidade por ruminantes, via aumento da digestão e consumo, pode ser alcançada pelo fornecimento de nutrientes suplementares, especialmente compostos nitrogenados.

Além disso, devido ao elevado custo das fontes proteicas tradicionais utilizadas na composição de suplementos múltiplos, como é o caso do farelo de soja, tem havido interesse em substituí-las por fontes alternativas regionais. Nesse enfoque, o farelo de algodão tem sido frequentemente utilizado em substituição ao farelo de soja, mas são necessários estudos para avaliar os possíveis impactos dessa fonte no ambiente ruminal. Ademais, quando se faz suplementação infrequente, há uma preocupação com as maiores quantidades de suplemento fornecidas nos dias de oferta, que podem promover alterações no ambiente ruminal e na eficiência de utilização da forragem.

Tem-se enfatizado que animais ruminantes sob suplementação infrequente, em dias alternados, mantêm elevados níveis de amônia e digestão da fibra similar à daqueles sob suplementação diária, mesmo nos dias em que não há oferta de suplemento. Esse fato tem sido atribuído à reciclagem de nitrogênio, notadamente entre os eventos de suplementação (Beaty et al., 1994; Farmer et al., 2004).

No entanto, os dados referentes aos efeitos da suplementação infrequente de bovinos em pastejo em condições tropicais ainda são escassos. Portanto, realizou-se este trabalho com o objetivo de avaliar suplementos à base de farelo de soja ou farelo de algodão e os efeitos da frequência de fornecimento desses suplementos sobre os parâmetros nutricionais de bovinos recriados em pastagens de Brachiaria brizantha cv. Marandu no período seco.

\section{Material e Métodos}

O experimento foi conduzido no setor de Nutrição de Bovinos em Pastejo, Fazenda Experimental da Universidade Federal de Mato Grosso, localizada no município de Santo Antônio do Leverger - Mato Grosso, durante a época seca, entre os meses de julho e setembro.

Foram utilizados cinco novilhos mestiços Nelore $\times$ Angus, castrados, compeso vivo médio inicial de $295 \pm 12,31 \mathrm{~kg}$, fistulados no rúmen, distribuídos individualmente em uma área composta de cinco piquetes de 0,24 ha, formados com Brachiaria brizantha cv. Marandu, providos de bebedouros e comedouros cobertos. Ao início de cada período experimental, os animais foram sorteados entre os suplementos e piquetes. O capim-braquiária foi estabelecido na área no mês de janeiro do ano de 2007, tratando-se, portanto de uma pastagem de primeiro ano. Os animais foram distribuídos em quadrado latino $5 \times 5$, com cinco estratégias de suplementação e cinco períodos experimentais. Cada período experimental teve duração de 19 dias, de modo que os nove primeiros dias de cada período foram destinados à amostragem da forragem e à adaptação dos animais.

Utilizaram-se dois suplementos isoproteicos, formulados com diferentes fontes de proteína verdadeira (farelo de soja ou farelo de algodão de alta energia) e fornecidos em duas frequências semanais (três vezes por semana, às segundas, quartas e sextas-feiras ou diariamente) em comparação à oferta de mistura mineral (controle), utilizada na formulação dos suplementos (Tabela 1).

Os suplementos foram formulados para conter 32\% de PB na matéria natural e foram fornecidos em cochos individuais, sempre às $10 \mathrm{~h}$, em quantidades equivalentes a 2,333 kg/animal/evento de suplementação, no caso dos animais sob suplementação três vezes por semana, e $1 \mathrm{~kg} / \mathrm{animal} / \mathrm{dia}$, no caso daqueles sob suplementação diariamente. Dessa forma, cada animal recebeu $7 \mathrm{~kg}$ de suplemento/semana.

Tabela 1 - Composição dos suplementos com farelo de algodão de alta energia e farelo de soja (\% matéria natural)

\begin{tabular}{lcc}
\hline Ingrediente & \multicolumn{2}{c}{ Suplemento } \\
\cline { 2 - 3 } & Farelo de algodão & Farelo de soja \\
\hline Mistura mineral $^{1}$ & 6,0 & 6,0 \\
Ureia/Sulfato de amônio (9:1) & 5,0 & 2,5 \\
Milho grão moído & 24,0 & 40,5 \\
Farelo de algodão de alta energia & \\
Farelo de soja & 65,0 & - \\
\hline
\end{tabular}

${ }^{1}$ Mistura mineral comercial - Ricofós 60 especial ${ }^{\circledR}$; Níveis de garantia por kg: cálcio - 198 g; fósforo - 60 g; sódio - 117 g; magnésio - 5,1 g; enxofre - 12,6 g; iodo - 17,7 mg; ferro - $425 \mathrm{mg}$; selênio - 10,4 mg; cobalto - $80 \mathrm{mg}$; manganês 527 mg; flúor - $600 \mathrm{mg}$; cobre - $1.000 \mathrm{mg}$; e zinco - $3.000 \mathrm{mg}$.

2 BUNGE Nutrição Animal. 
Os animais foram pesados no início e ao final de cada período experimental, sem jejum prévio e sempre às $7 \mathrm{~h}$. Após a pesagem inicial, foram distribuídos aleatoriamente nos grupos.

Em virtude da pequena área experimental e dos períodos relativamente curtos, achou-se conveniente a amostragem da forragem apenas no primeiro dia dos períodos 1 , 3 e 5 , correspondentes aos meses de julho, agosto e setembro, pelo corte a $5 \mathrm{~cm}$ do solo, de três áreas escolhidas aleatoriamente e delimitadas por um quadrado metálico de $0,5 \times 0,5 \mathrm{~m}$. Após a coleta, as amostras de cada piquete foram pesadas e homogeneizadas e, do material homogeneizado, foram retiradas duas alíquotas compostas: uma para avaliação da disponibilidade total de matéria seca (MS)/ha e outra para análise da disponibilidade de MS/ha de folha verde, folha seca, colmo verde e colmo seco (Tabela 2). A amostragem da forragem consumida pelos animais foi feita no terceiro dia do período experimental, via simulação manual do pastejo animal, realizada por duas pessoas treinadas percorrendo toda a área.

Das amostras destinadas à estimação da disponibilidade total de MS de forragem (planta inteira) foi calculado o percentual de MS potencialmente digestível (MSpD) ofertada aos animais. Esse resultado foi obtido por intermédio do resíduo insolúvel em detergente neutro avaliado após incubação in situ das amostras por 144 horas, segundo a equação: $\mathrm{MSpD}=0,98 \times(100-\mathrm{FDN})+($ FDN FDNi), onde: 0,98 = coeficiente de digestibilidade verdadeiro do conteúdo celular; FDN = fibra em detergente neutro; FDNi $=$ FDN indigestível.

Para estimativa da excreção de MS fecal, utilizaram-se 10 g de óxido crômico (Burns et al., 1994) diariamente, acondicionados em cartucho de papel e introduzidos diretamente no rúmen em dose única às $11 \mathrm{~h}$ do 3 으 ao $11^{\circ}$ dia de cada período experimental. Posteriormente, realizaram-se três coletas de amostra de fezes (aproximadamente $300 \mathrm{~g}$ ) diretamente do reto: no 90 dia às $8 \mathrm{~h}$; no $10^{0}$ dia às $12 \mathrm{~h}$; e no 11 을 às $18 \mathrm{~h}$, realizando-se uma amostra composta por animal e por período. Imediatamente após a coleta, as amostras de fezes foram acondicionadas em sacos plásticos, identificadas e congeladas a $-10^{\circ} \mathrm{C}$.

As amostras de fezes e de forragem foram pré-secas em estufa com ventilação forçada a $60^{\circ} \mathrm{C}$ por 72 horas e trituradas em moinho de facas com peneira com crivos de $1,0 \mathrm{~mm}$. As amostras de fezes foram compostas por animal e por período e armazenadas em frascos de plásticos identificados para posteriores análises.

A estimativa da excreção de MS fecal foi realizada considerando-se a razão entre a quantidade de indicador fornecido e sua concentração nas fezes:

Excreção fecal $=[$ Quantidade de cromo fornecida (g) / concentração de cromo nas fezes (g/kg MS fecal)].

A fibra em detergente neutro indigestível (FDNi) foi utilizada como indicador da digestibilidade da dieta. A concentração de FDNi foi determinada nas amostras de pastejo simulado, suplementos e fezes por intermédio da incubação in situ por 144 horas, segundo método descrito por Cochran et al. (1986). As estimativas do consumo voluntário foram obtidas empregando-se a equação: $\mathrm{CMS}=\{[(\mathrm{EF} \times \mathrm{CIF})-\mathrm{IS}] / \mathrm{CIFO}\}+$ CMSS em que CMS $(\mathrm{kg} / \mathrm{dia})=$ consumo de matéria seca; $\mathrm{EF}=$ excreção fecal ( kg/dia); CIF = concentração do indicador nas fezes $(\mathrm{kg} / \mathrm{kg})$; IS = indicador presente no suplemento $(\mathrm{kg} / \mathrm{dia}) ; \mathrm{CIFO}=$ concentração do indicador na forragem $(\mathrm{kg} / \mathrm{kg})$ e CMSS = consumo de matéria seca de suplemento (kg/dia).

Tabela 2 - Composição nutricional dos suplementos e da forragem, com base na matéria seca

\begin{tabular}{|c|c|c|c|}
\hline Item & \multicolumn{2}{|c|}{ Suplemento } & B. brizantha ${ }^{1}$ \\
\hline Matéria seca (\%) & 89,48 & 89,41 & 49,93 \\
\hline Proteína bruta (\% MS) & 35,23 & 35,15 & 4,54 \\
\hline Nitrogênio insolúvel em detergente neutro (\% $\mathrm{N}$ total) & 2,22 & 6,09 & 50,98 \\
\hline Nitrogênio insolúvel em detergente ácido (\% $\mathrm{N}$ total) & 1,26 & 4,16 & 14,49 \\
\hline Fibra em detergente neutro, FDN (\% MS) & 15,26 & 30,43 & 72,72 \\
\hline FDNcp (\% MS) & 13,55 & 27,21 & 69,11 \\
\hline Fibra em detergente neutro indigestível (\% MS) & 2,88 & 12,48 & 21,47 \\
\hline Fibra em detergente ácido (\% MS) & 8,65 & 22,23 & 42,50 \\
\hline Carboidratos totais (\% MS) & 53,35 & 50,91 & 87,22 \\
\hline Carboidratos não-fibrosos (\% MS) & 46,3 & 44,27 & 14,5 \\
\hline
\end{tabular}

\footnotetext{
${ }^{1}$ Simulação do pastejo; ${ }^{2}$ NRC (2001).
} 
No 120 dia de cada período experimental, quatro horas após o fornecimento do suplemento, realizaram-se as coletas de sangue, para determinação de ureia no soro. Em seguida, procedeu-se à centrifugação das amostras a $4000 \mathrm{rpm}$, durante 15 minutos. O soro sanguíneo foi congelado a $20^{\circ} \mathrm{C}$ para posterior quantificação dos teores de uréia (Valadares et al., 1999).

Para avaliação do pH e da concentração de amônia no líquido ruminal, as amostras foram coletadas manualmente em três dias: um dia em que somente os animais sob suplementação diária receberam suplemento; outro quando todos receberam suplemento; e novamente quando somente aqueles do grupo com suplementação diária receberam suplemento. As coletas foram realizadas imediatamente antes da suplementação (tempo zero) e 4 horas após o fornecimento do suplemento (tempo quatro), na região de interface líquido/sólido do ambiente ruminal, e filtradas por uma camada tripla de gaze. $\mathrm{O} \mathrm{pH}$ foi medido imediatamente após a coleta utilizando-se peagâmetro digital. Para determinação da concentração de amônia, separou-se uma alíquota de $50 \mathrm{~mL}$, que foi fixada com $1 \mathrm{~mL}$ de solução de $\mathrm{H}_{2} \mathrm{SO}_{4} 1: 1$ e acondicionada em recipiente de plástico com tampa, identificada e congelada a $-20^{\circ} \mathrm{C}$ para posterior análise laboratorial. As concentrações de $\mathrm{N}-\mathrm{NH}_{3}$ do líquido ruminal foram determinadas mediante destilação com hidróxido de potássio 2N, de acordo com a técnica descrita por Fenner (1965) adaptada por Vieira (1980).

As determinações da MS, matéria orgânica (MO), PB, FDN, fibra em detergente ácido (FDA), FDN corrigida para cinzas e proteína (FDNcp), EE e matéria mineral foram realizadas de acordo com descrições de Silva \& Queiroz (2002). Os resíduos da FDN e FDA foram utilizados para determinação do nitrogênio insolúvel em detergente neutro (NIDN) e ácido (NIDA), respectivamente, de acordo com Van Soest et al. (1991).

Os teores de carboidratos totais dos alimentos (CT) foram calculados segundo Sniffen et al. (1992): CT = $100-$ (\%PB + \%ЕE + \%MM).

A quantificação dos carboidratos não-fibrosos (CNF) dos suplementos foi realizada de acordo com adaptação de Hall (2000), uma vez que foi incluída ureia na composição dos suplementos pela seguinte equação: $\mathrm{CNF}=100-[(\% \mathrm{~PB}$ - \%PB da ureia + \%ureia) $+\%$ FDNcp $+\%$ EE + \%cinzas $]$.

Com base na composição químico-bromatológica dos alimentos, os teores de NDT foram estimados segundo o NRC (2001), pela equação: NDT $(\%)=($ PBD + CNFD + FDNpD + EED $\times 2,25)-7$, em que a constante 7 refere-se ao valor metabólico fecal.

Os valores de proteína bruta digestível (PBD), ácidos graxos digestíveis (AGD), fibra em detergente neutro corrigida para proteína digestível (FDNpD) e carboidratos não-fibrosos digestíveis (CNFD) foram estimados de acordo com as seguintes equações:

$\mathrm{PBD}($ concentrados $)=\mathrm{PB} \times[1-(0,4 \times \mathrm{PIDA} / \mathrm{PB})]$; $\mathrm{AGD}=(\mathrm{EE}-1) \times 100 ; \mathrm{CNFD}=(0,98 \times \mathrm{CNF} \times \mathrm{PAF}) ; \mathrm{FDNpD}=$ $0,75 \times(\mathrm{FDNp}-\mathrm{L}) \times\left(1-(\mathrm{L} / \mathrm{FDNp})^{0,667}\right.$; em que: PIDA proteína insolúvel em detergente em detergente ácido; PAF - fator de ajuste para processamento físico (farelo de algodão =1,04; grão de milho moído = 1,00; farelo de soja = 1,00); L = lignina e FDNp = FDN corrigida para proteína.

O experimento foi analisado segundo um delineamento quadrado latino $5 \times 5$ conforme o seguinte modelo:

$$
\mathrm{Y}_{\mathrm{ijk}}=\mu+t_{\mathrm{i}}+\mathrm{a}_{\mathrm{j}}+p_{\mathrm{k}}+\varepsilon_{\mathrm{ijk}} ;
$$

em que: $\mu=$ constante geral; $t_{\mathrm{i}}=$ efeito referente ao tratamento $\mathrm{i} ; a_{\mathrm{j}}=$ efeito referente ao animal $\mathrm{j} ; p_{\mathrm{k}}=$ efeito referente ao período experimental k; e $\varepsilon_{\mathrm{ijk}}=$ erro aleatório, associado a cada observação, pressuposto NID $\left(0 ; \sigma^{2}\right)$.

Os procedimentos estatísticos foram realizados pelo programa SAS (Statistical Analysis System), adotando-se 0,05 como nível crítico de probabilidade. Os contrastes ortogonais foram utilizados para partição específica dos efeitos de tratamento, comparando-se controle (mistura mineral) versus suplementação, farelo de soja versus farelo de algodão de alta energia e frequência sete vezes versus três vezes.

\section{Resultados e Discussão}

As disponibilidades médias de matéria seca total, matéria seca potencialmente digestível (DMSpD), matéria seca de folhas verdes, matéria seca de folhas secas, matéria seca de colmos verdes e matéria seca de colmos secos foram $3.980 ; 2.591 ; 109 ; 1.291 ; 547 ; 2.033 \mathrm{~kg} / \mathrm{ha}$, respectivamente (Figura 1).

Conforme avança o período de seca, e também em virtude da ação dos animais, há alterações consideráveis na estrutura da forragem, especialmente na fração folhas verdes, que reduz drasticamente. Embora tenham sido observados valores expressivos de disponibilidade de MS total, esse fato não refletiu diretamente na qualidade da forragem, haja vista a considerável diferenciação morfológica no decorrer do período experimental. Como resultado da reduzida disponibilidade de folhas verdes e do aumento na proporção de colmo, os teores de PB da forragem obtidos por simulação de pastejo (Tabela 2) estiveram bem aquém do valor relatado por Van Soest (1994), de no mínimo $7 \%$, para que a microbiota ruminal tenha condições de utilizar os substratos energéticos potencialmente utilizáveis da forragem. 


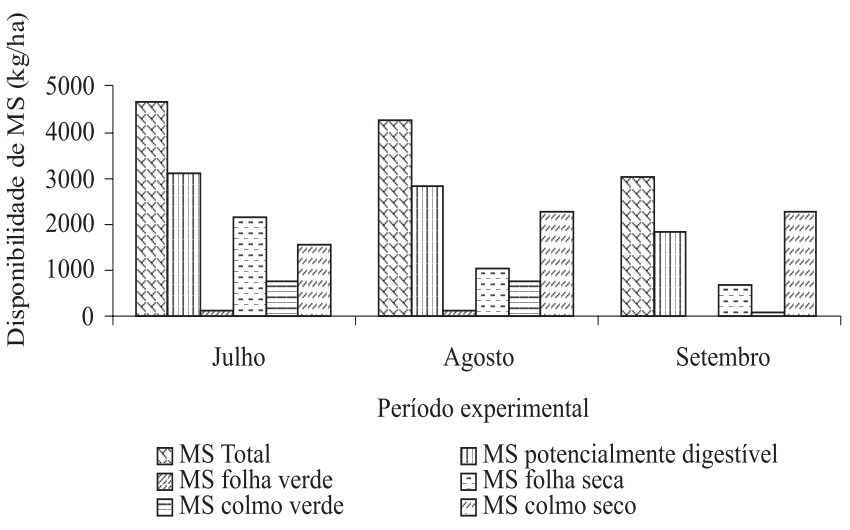

Figura 1 - Disponibilidade de matéria seca da forragem nos meses de julho, agosto e setembro.

A disponibilidade média de MS potencialmente digestível durante o experimento foi de $2.591 \mathrm{~kg} / \mathrm{ha}$, que representa aproximadamente $65 \%$ da disponibilidade de MS total. Segundo Paulino et al. (2006), os efeitos do aumento nessa disponibilidade de MS potencialmente digestível no sistema de produção são verificados de forma direta, uma vez que o aumento na disponibilidade de forragem de melhor qualidade diminui a necessidade de suplemento no sistema.

Houve efeito $(\mathrm{P}<0,05)$ da suplementação no consumo diário de PB, EE e carboidratos não-fibrosos.

O fato de a suplementação não ter influenciado o consumo de MS total (Tabela 3) não era esperado, ou seja, não corresponde a relatos observados em estudos com forragem de baixa qualidade como a utilizada neste estudo, em que a inclusão de suplementos proteicos à dieta geralmente promove melhoria no ambiente ruminal e no consumo (DelCurto et al., 1990). Todavia, outros fatores, como a alteração na estrutura do dossel forrageiro (elevada proporção de colmo seco em detrimento à disponibilidade de folhas) (Figura 1), podem ter contribuído para ausência desse efeito, haja vista a capacidade dessa fração em promover repleção ruminal e reduzir o fluxo de digesta para o trato posterior .

As fontes proteicas tiveram efeito $(\mathrm{P}<0,05)$ somente sobre o consumo de EE (Tabela 3), que foi maior para os animais sob suplementação com farelo de algodão, em decorrência do maior nível de extrato etéreo nesse suplemento.

$\mathrm{O}$ fornecimento infrequente de suplemento aumentou $(\mathrm{P}<0,05)$ o consumo de MS total e de MS da forragem. Todavia, Beaty et al. (1994) e Huston et al. (1999) observaram maiores consumos de MS de forragem em animais sob suplementação diariamente em comparação a animais sob suplementação 3 vezes/semana. Segundo esses autores, a

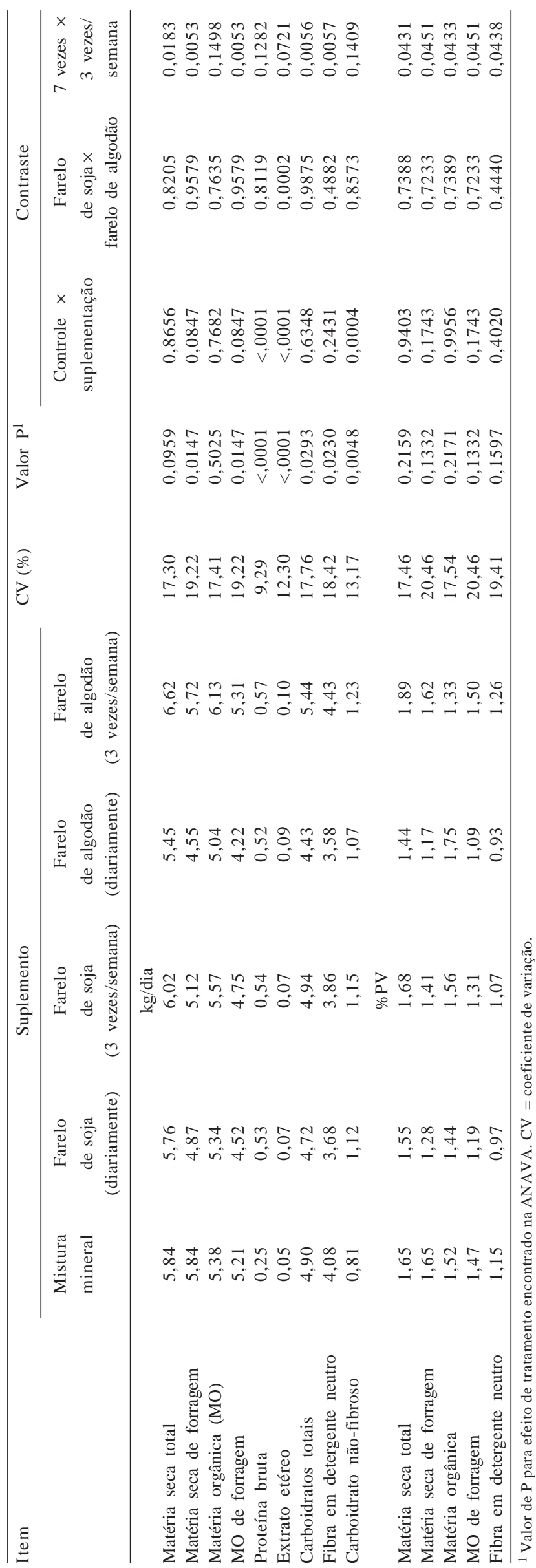

R. Bras. Zootec., v.40, n.4, p.882-891, 2011 
redução no consumo de forragem quando o suplemento foi fornecido 3 vezes por semana pode ser uma resposta às maiores quantidades de suplemento consumido por evento de suplementação. Beaty et al. (1994) não observaram influência das frequências de suplementação sobre o consumo de MS total e atribuíram esse fato à quantidade de suplemento fornecida semanalmente, que foi a mesma para todos os animais.

Acredita-se que a baixa qualidade da forragem deste estudo contribuiu sobremaneira para os maiores consumos de MS total entre os animais sob suplementação 3 vezes/ semana, uma vez que, nos dias de suplementação, recebiam maior quantidade de suplemento, embora essa maior quantidade consumida não promovesse efeitos deletérios no consumo de forragem. Adicionalmente, nos intervalos de suplementação (dias sem suplementação), o consumo de forragem era maior.

Também foram observados maiores consumos $(\mathrm{P}<0,05)$ de MO da forragem, carboidratos totais e FDN no grupo sob suplementação 3 vezes por semana, o que pode ser explicado pelos maiores consumos de forragem. O fornecimento infrequente de suplemento não influenciou os consumos de PB, EE e CNF, possivelmente porque as quantidades de suplemento oferecida eram as mesmas nos dois grupos.

Não foram observadas diferenças significativas nos consumos expressos em porcentagem do peso vivo. Esse fato não era esperado, uma vez que houve diferenças nos consumos expressos em $\mathrm{kg} / \mathrm{dia}$, logo, entende-se que uma possível variação na uniformidade dos animais utilizados tenha resultado nesta divergência. A suplementação teve efeito positivo $(\mathrm{P}<0,05)$ na digestibilidade da proteína bruta (Tabela 4).

Valores positivos de digestibilidade ruminal da $\mathrm{PB}$ são indicativos de que não houve deficiência de compostos nitrogenados na dieta (Detmann et al., 2005). Bohnert et al. (2002b) observaram que a suplementação proteica proporcionou digestibilidade aparente total do $\mathrm{N}$ aproximadamente $170 \%$ maior que a observada com o fornecimento de mistura mineral. De acordo com os autores, a baixa digestibilidade do nitrogênio em animais recebendo apenas mistura mineral provavelmente se deve aos maiores teores de fibra e aos menores de PB em forragem de baixa qualidade. Isso resulta em proporção significativa do $\mathrm{N}$ nas fezes (N metabólico fecal).

A digestibilidade total da FDN reduziu com a suplementação aos animais, fato que diverge do observado quando fornecida forragem de baixa qualidade, uma vez que a suplementação proteica geralmente aumenta a digestão de compostos fibrosos e da MS. Efeitos deletérios na digestão ruminal da fibra têm sido normalmente associados

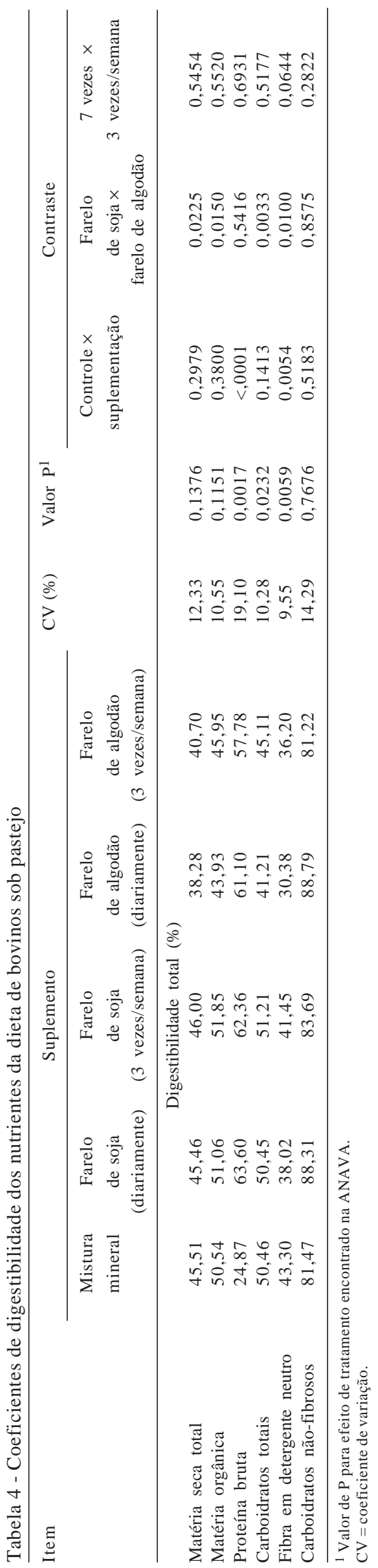

R. Bras. Zootec., v.40, n.4, p.882-891, 2011 
à adição de carboidratos não-fibrosos à dieta, que resulta em dois efeitos distintos, segundo Detmann et al. (2005): efeito pH (redução do pH ruminal) e efeito concentrado (competição por nutrientes entre microrganismos fibrolíticos e aqueles que degradam a carboidratos não-fibrosos). No entanto, considerando os baixos níveis de suplementação e o pH satisfatório, pouco se pode atribuir a esses efeitos. Logo, entende-se que uma alteração na prioridade por substrato pelos microrganismos ruminais pode ter contribuído para esses resultados.

De acordo com Mertens \& Loften (1980), citados por Detmann et al. (2005), a simples competição entre digestão e passagem poderia justificar boa parte dessa redução da digestão da fibra, não permitindo, no entanto, descartar alguma influência da adição de carboidratos não-fibrosos à dieta sobre o aumento do tempo de colonização da fibra.

A suplementação com farelo de algodão reduziu $(\mathrm{P}<0,05)$ as digestibilidades totais da FDN e dos carboidratos totais, possivelmente devido aos maiores níveis de componentes fibrosos desse suplemento. Além disso, a maior oferta de nitrogênio não-proteico via suplemento com farelo de algodão pode ter contribuído para esses resultados, dada a possível falta de sincronia entre as taxas de degradação e passagem das frações carboidratos e proteína da dieta.

O fornecimento do suplemento 3 vezes/semana não afetou as digestibilidades dos nutrientes da dieta. Inúmeros fatores podem interferir na digestibilidade dos nutrientes e, de maneira geral, a suplementação 3 vezes/semana e as fontes proteicas estudadas pouco interferiram na digestibilidade dos nutrientes. No entanto, os baixos coeficientes encontrados neste estudo, mesmo quando se forneceu suplemento, podem ser atribuídos à baixa qualidade da forragem.

Não houve efeito $(\mathrm{P}>0,05)$ das fontes proteicas nem das frequências de fornecimento do suplemento sobre o $\mathrm{pH}$ do líquido ruminal em nenhum dos tempos de mensuração (Tabela 5; Figuras 2 e 3).

Os resultados deste estudo diferem daqueles encontrados por Bohnert et al. (2002c), que verificaram decréscimos no pH com a suplementação proteica, possivelmente em virtude dos baixos níveis de suplementação praticados. Embora não tenham sido verificadas diferenças entre as fontes proteicas, observou-se que o suplemento com farelo de algodão de alta energia foi consumido mais lentamente, possivelmente em virtude do seu maior teor de ureia, que pode contribuir para menores quedas no $\mathrm{pH}$ ruminal.

Mesmo no dia em que os animais do grupo 3 vezes/ semana receberam suplemento, em que a quantidade de suplemento fornecida foi maior, os valores de $\mathrm{pH}$ ruminal permaneceram em níveis adequados ao crescimento e à

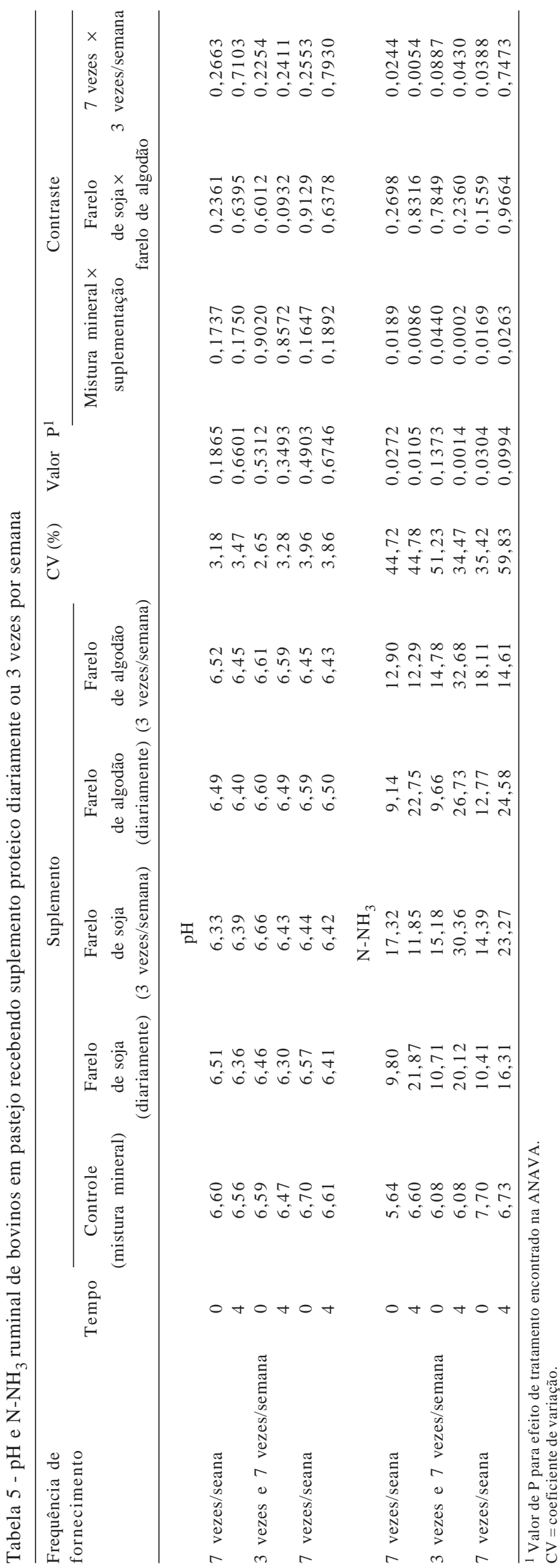

R. Bras. Zootec., v.40, n.4, p.882-891, 2011 


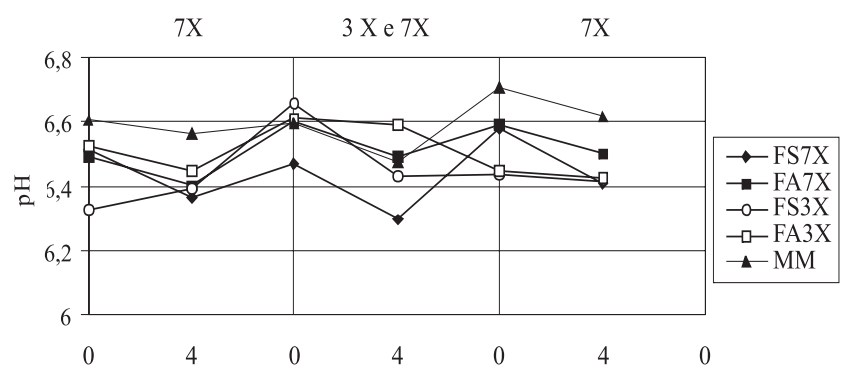

Figura 2 - pHruminal de bovinos em pastejo recebendo suplementos proteicos diariamente ou três vezes/semana.

atividade dos microrganismos celulolíticos. Beaty et al.(1994) verificaram que, nos dias de intervalo da suplementação, o pH ruminal de animais sob suplementação 3 vezes/semana permanecia mais elevado que o daqueles sob suplementação diária. Em contraste, nos dias em que ambos os grupos receberam suplemento, o pH dos animais sob suplementação 3 vezes/semana declinou mais acentuadamente às 4, 8, 12 e 24 horas após a suplementação em comparação ao daqueles que receberam suplemento diariamente, embora sem comprometimento na digestão da fibra.

Estudos conduzidos no Brasil têm comprovado que, mesmo níveis elevados de suplementação não causam distúrbios severos no $\mathrm{pH}$ ruminal, possivelmente um reflexo da alta efetividade física da fibra de gramíneas tropicais sob pastejo, notadamente no período seco do ano (Paulino et al., 2006). Esse fato também reforça a ausência de efeitos das fontes proteicas.

Outro ponto importante é o fato de os animais sob suplementação 3 vezes/semana não consumirem todo o suplemento de uma única vez, o que pode ter evitado quedas mais severas no $\mathrm{pH}$ decorrentes da suplementação (Figura 2). Houve efeito da suplementação $(\mathrm{P}<0,05)$ sobre a concentração de $\mathrm{N}-\mathrm{NH}_{3}$ ruminal, exceto no tempo zero (antes do fornecimento do suplemento) do dia em que todos os animais receberam suplemento, o que provavelmente foi resultado do maior período sem suplemento, tanto para aqueles que receberam o suplemento diariamente como para aqueles que o receberam em dias alternados (Figura 3).

De acordo com Del Curto et al. (1990), a suplementação proteica tem sido associada a aumento na concentração de $\mathrm{N}-\mathrm{NH}_{3}$ no ambiente ruminal, e esse acréscimo possibilita maior crescimento microbiano e degradação da forragem. Esse fato tem grande importância, sobretudo no caso de forragem com baixos níveis proteicos. Todavia, apesar das maiores concentrações de $\mathrm{N}-\mathrm{NH}_{3}$ nos animais sob suplementação, não houve benefícios na digestibilidade da FDN, possivelmente em virtude da elevada proporção de colmo na forragem.

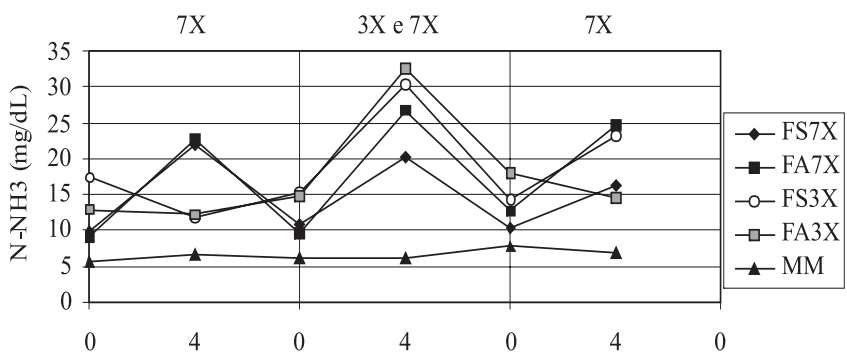

Figura 3 - Concentrações de nitrogênio amoniacal ruminal em bovinos em pastejo recebendo suplemento proteico diariamente ou três vezes/semana.

As fontes proteicas utilizadas no suplemento não tiveram efeitos $(\mathrm{P}>0,05)$ sobre os valores de $\mathrm{N}-\mathrm{NH}_{3}$ ruminal, o que pode ser atribuído ao fato de os suplementos serem isoproteicos. No entanto, esperava-se que os suplementos com farelo de algodão proporcionassem maiores concentrações de $\mathrm{N}-\mathrm{NH}_{3}$, em virtude dos maiores níveis de uréia na composição.

Mesmo no dia em que não receberam suplemento, as concentrações de $\mathrm{N}-\mathrm{NH}_{3}$ no tempo zero dos grupos sob suplementação 3 vezes/semana foi mais alta $(P<0,05)$, como reflexo da maior quantidade de suplemento recebido no dia anterior e/ou da reciclagem endógena de nitrogênio (Tabela 5; Figura 3).

Nos dias de suplementação, a concentração de nitrogênio amoniacal 4 horas após o consumo do suplemento (Figura 3) nos animais que receberam suplemento diariamente geralmente foi maior que naqueles sob suplementação em dias alternados. Entretanto, nos dias em que ambos os grupos receberam suplemento, o pico de concentração de nitrogênio amoniacal nos animais sob suplementação 3 vezes por semana foi maior (Figura 3), o que pode ser facilmente explicado pela maior quantidade de suplemento fornecida.

Bohnert et al. (2002b) ressaltaram que animais ruminantes podem ser hábeis em conservar nitrogênio por longos períodos, possivelmente em virtude das mudanças na permeabilidade do trato gastrintestinal a ureia e/ou pela regulação da excreção renal, mantendo o fornecimento de nitrogênio entre os intervalos de suplementação. Esse fato sugere que a amônia ruminal entre os eventos de suplementação pode ser mantida em concentrações similares à de animais sob suplementação diariamente, como resultado de um ativo sistema de reciclagem endógena de nitrogênio desses animais, o que permite sustentar a digestão da fibra (Beaty et al., 1994; Bohnert et al., 2002a).

No terceiro dia de avaliação, os animais que receberam suplemento 3 vezes/semana, embora não tivessem recebido suplemento na data, apresentaram aumento nas

R. Bras. Zootec., v.40, n.4, p.882-891, 2011 
concentrações de N-NH , que estavam em declínio (Figura 3). Pressupõe-se, portanto, que esse evento tenha sido resultado do sistema de reciclagem endógena de nitrogênio. Além disso, em virtude do nível de fornecimento e do nível de ureia no suplemento, sobretudo no grupo que recebeu farelo de algodão em dias alternados, os animais não consumiam todo suplemento de uma só vez. É possível que esse fato tenha refletido nas concentrações de nitrogênio amoniacal no decorrer do dia.

Outro ponto importante a ser ressaltado é o pico de nitrogênio amoniacal no tempo 4 (Figura 3 ) nos animais que receberam farelo de algodão diariamente ou 7 vezes por semana, fato que pode ser reflexo do maior nível de ureia na composição desse suplemento, que apresenta elevadas taxas de hidrólise no rúmen.

De modo geral, em todos os grupos, e mesmo nos dias sem suplementação, as concentrações médias de $\mathrm{N}-\mathrm{NH}_{3}$ ruminal estiveram sempre acima do nível de 5,0 mg/dL de líquido ruminal, relatado por Satter \& Slyter (1974) como não-limitante à síntese microbiana. Com exceção do grupo controle, o $\mathrm{N}-\mathrm{NH}_{3}$ também se manteve acima do valor recomendado por Leng (1990) e Lazzarini (2007), de 10,0 mg de $\mathrm{N}-\mathrm{NH}_{3} / \mathrm{dL}$ de líquido ruminal, como adequado à fermentação ruminal em condições tropicais. No entanto, embora as concentrações de nitrogênio amoniacal dos animais sob suplementação tenham permanecido em níveis adequados, esse fato não refletiu em melhor digestibilidade da fração fibrosa da dieta (Tabela 4).

As concentrações séricas de nitrogênio ureico diferiram significativamente entre os animais sob suplementação $(\mathrm{P}<0,05)$ e aqueles do grupo controle (Figura 4$)$.

O nitrogênio ureico sérico tem sido frequentemente utilizado na obtenção de informações adicionais do status da nutrição proteica de ruminantes em resposta à determinada dieta. De acordo com Valadares et al. (1997), os níveis plasmáticos de uréia, variando de 13,52 e 15,15 mg/dL, correspondem à máxima eficiência microbiana e possivelmente representariam o máximo, a partir do qual estaria

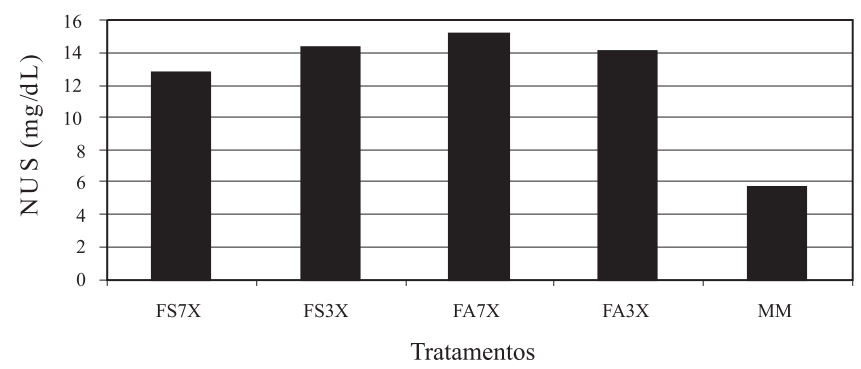

Figura 4 - Concentrações séricas de nitrogênio ureico em bovinos em pastejo sob suplementação diária ou três vezes/ semana. ocorrendo perda de proteína em novilhos zebuínos alimentados com ração com aproximadamente $62,5 \%$ de nutrientes digestíveis totais. Portanto, exceto a mistura mineral (controle), os suplementos proteicos possibilitaram aproveitamento eficiente do nitrogênio da dieta, mesmo aquele com farelo de algodão, com maior nível de ureia em sua composição.

Krehbiel et al. (1998) e Bohnert et al. (2002b) também observaram aumento na concentração de nitrogênio ureico no plasma quando forneceram suplemento proteico a animais consumindo forragem de baixa qualidade.

Adicionalmente, Krehbiel et al. (1998) observaram que ruminantes consumindo forragem de baixa qualidade e suplemento com farelo de soja a cada três dias apresentaram maior remoção de ureia pelas vísceras, resultando em manutenção ou aumento na economia de nitrogênio para os microrganismos no rúmen.

\section{Conclusões}

A suplementação três vezes por semana e as fontes proteicas estudadas são alternativas de manejo viáveis para sistemas de produção pasto-suplemento, uma vez que possibilitam parâmetros nutricionais adequados, mesmos nos dias sem suplementação.

\section{Referências}

BEATY, J.L.; COCHRAN, R.C.; LINTZENICH, B.A. et al. Effect of frequency of supplementation and protein concentration in supplements on performance and digestion characteristics of beef cattle consuming low-quality forages. Journal of Animal Science, v.72, n.9, p.2475-2486, 1994.

BERCHIELLI, T.T.; CANESIN, R.C.; ANDRADE, P. Estratégias de Suplementação para Ruminantes em Pastagem. In: REUNIÃO ANUAL DA SOCIEDADE BRASILEIRA DE ZOOTECNIA, 43., 2006, João Pessoa. Anais... João Pessoa: Sociedade Brasileira de Zootecnia, 2006. (CD-ROM).

BOHNERT, D.W.; SCHAUER, C.S.; BAUER, M.L. et al. Influence of rumen protein degradability and supplementation frequency on steers consuming low-quality low-quality forage: I-Site of digestion and microbial efficiency. Journal of Animal Science, v.80, n.11, p.2967-2967, 2002a.

BOHNERT, D.W.; SCHAUER, C.S.; DELCURTO, T. Influence of rumen protein degradability and supplementation frequency on performance and nitrogen use in ruminants consuming lowquality forage: Cow performance and efficiency of nitrogen use in wethers. Journal of Animal Science, v.80, n.6, p.16291637, 2002b.

BOHNERT, D.W.; SCHAUER, C.S.; FALCK, S.J. et al. Influence of rumen protein degradability and supplementation frequency on steers consuming low-quality forage: II. Ruminal fermentation characteristics. Journal of Animal Science, v.80, n.11, p.2978-2988, 2002c.

BURNS, J.C.; POND, K.R.; FISHER, D.S. Measurament of forage intake. In: FAHEY JUNIOR, G.C. Forage quality, evaluation and utilization. Madison: America Society of Agronomy, 1994. p.494-531. 
COCHRAN, R.C.; ADAMS, D.C.; WALLACE, J.D. et al. Predicting digestibility of different diets with internal markers: Evaluation of four potential markers. Journal of Animal Science, v.63, n.5, p.1476-1483, 1986.

DELCURTO, T.; COCHRAN, R.C.; HARMON, D.L. et al. Supplementation of Dormant Tallgrass-prairie forage: I. Influence of varying supplemental protein and (or) energy levels on forage utilization characteristics of beef steers in confinement. Journal Animal Science, v.68, n.2, p.515-531, 1990 .

DETMANN, E.; PAULINO, M.F.; VALADARES FILHO, S.C. et al. Níveis de proteína em suplementos para terminação de bovinos em pastejo durante o período de transição seca/águas: Digestibilidade aparente e parâmetros do metabolismo ruminal e dos compostos nitrogenados. Revista Brasileira de Zootecnia, v.34, n.4, p.1380-1391, 2005.

FARMER, C.G.; COCHRAN, R.C.; NAGARAJA, T.G. et al. Ruminal and host adaptaptations to change in frequency of protein supplementation. Journal of Animal Science, v.82, n.3, p.895-903, 2004.

HALL, M.B. Calculation of non-structural carbohydrate content of feeds that contain non-protein nitrogen. University of Florida, 2000. p.A-25 (Bulletin 339).

HUSTON, J.E.; LIPPKE, H.; FORBES, T.D. et al. Effects of supplemental feeding interval on adult cows in western Texas. Journal of Animal Science, v.77, n.11, p.3057-3067, 1999.

KREHBIEL, C.R.; FERRELL, C.L.; FREETLY, H.C. et al. Effects of frequency of supplementation on Dry matter intake and net portal and hepatic flux of nutrients in mature ewes that consume low-quality forage. Journal of Animal Science, v.76, n.9, p.2464-2473, 1998.

KÖSTER, H.H.; COCHRAN, R.C.; TITGEMEYER, E.C. et al. Effect of increasing degradable intake protein on intake and digestion of low-quality, tall grass prairie forage by beef cows. Journal of Animal Science, v.74, n.10, p.2473-2481, 1996.

LAZZARINI, I.; DETMANN, E.; SAMPAIO, C.B. et al. Intake and digestibility in cattle fed low-quality tropical forage and supplemented with nitrogenous compounds. Revista Brasileira de Zootecnia, v.38, n.10, p. 2021-2030, 2009.

LENG, R.A. Factors affecting the utilization of "poor-quality" forages by ruminants particularly under tropical conditions. Nutrition Research Review, v.3, n.3, p.277-303, 1990.
NATIONAL RESEARCH COUNCIL - NRC. Nutrients requirements of dairy cattle. 7.ed. Washington: National Academy Press, 2001. 381p.

PAULINO, M.F.; DETMANN, E.; VALADARES FILHO, S.C. Suplementação animal em pasto: energética ou protéica? In: SIMPÓSIO SOBRE MANEJO ESTRATÉGICO DA PASTAGEM, 3., 2006, Viçosa, MG. Anais... Viçosa, MG? 2006, p.359-392.

SATTER, L.D.; SLYTER, L.L. Effect of ammonia concentration on rumen microbial production in vitro. British Journal of Nutrition, v.32, n.2, p.199-208, 1974.

SILVA, D.J.; QUEIROZ, A.C. Análise de alimentos: métodos químicos e biológicos. 3.ed. Viçosa, MG: Imp. Univ., 2002. 165p.

SNIFFEN, C.J.; O’CONNOR, J.D.; VAN SOEST, P.J. et al. A net carbohydrate and protein system for evaluating cattle diets; II. Carbohydrate and protein availability. Journal of Animal Science, v.70, n.11, p.3562-3577, 1992.

VALADARES FILHO, S.C.; MORAES, E.H.B.K.; DETMANN, E. et al. Perspectiva do uso de indicadores para estimar o consumo individual de bovinos alimentados em grupo. In: REUNIÃO ANUAL DA SOCIEDADE BRASILEIRA DE ZOOTECNIA, 43., 2006, João Pessoa. Anais... João Pessoa: Sociedade Brasileira de Zootecnia, 2006. (CD-ROM).

VALADARES, R.F.D.; BRODERICK, G.A.; VALADARES FILHO, S.C. et al. Effect of replacing alfalfa silage with high moisture corn on ruminal protein synthesis estimated from excretion of total purine derivatives. Journal of Dairy Science, v.82, n.11, p.2686-2696, 1999.

VALADARES, R.F.D.; GONÇALVES, L.C.; RODRIGUEZ, N.M. et al. Níveis de proteína em dieta de bovinos. 4 Concentrações de Amônia ruminal e uréia plasmática e excreções de uréia e creatinina. Revista Brasileira de Zootecnia, v.26, n.6, p.1270-1278, 1997.

VAN SOEST, P.J. Nutritional ecology of the ruminant. 2ed. Ithaca: Cornell University, 1994. 476p.

VAN SOEST, P.J.; ROBERTSON, J.B.; LEWIS, B.A. Methods for dietary fiber, Neutral detergent fiber, and nonstarch polysaccharides in relation to animal nutrition. Journal of Dairy Science, v.74, n.10, p.3583-3597, 1991.

VIEIRA, P.F. Efeito do formaldeído na proteção de proteínas e lipídeos em rações para ruminantes. 1980. 98f. Tese (Doutorado em Zootecnia) - Universidade Federal de Viçosa, Viçosa, MG. 